\title{
To Deso A. Weiss' 60th Birthday
}

On October 31st, 1961, Deso Weiss will celebrate his 60th birthday and I welcome this occasion to honor a man whom I hold in such high esteem not only as a scientist but as a personal friend. When I first offered to write this article my only reservation stemmed from the thought that perhaps I could not be objective enough in judging Weiss' personality and scientific work. I must admit that through the years I have known Deso Weiss there has developed within me a feeling like that of a father toward a son. However, I am sure that the value I place on both my scientific experience and my personal relationship with this man stem from his character which I would describe as that of an honest noble gentleman. For almost forty years I have had the pleasure of maintaining a close connection with my former student and I can state without reservation he has never done anything of which I could not be proud. Among the things to admire in this man's personality are his broad social attitude toward his

12 Kulia Phoniatrica, Vol. 13, No. 3 (1961)

162

To Deso A. Weiss’ 60th Birthday

fellowmen, his readiness to give and take friendship, his constant urgent desire to help people, not only patients, his search for truth, his great modesty and last but not least, his courageous attitude toward the hardship that at times fate has thrown in his way. Another admirable trait of this man is his ability to exercise objective scientific judgment toward the work and ideas of other people and to refrain from coloring his scientific views with any differences of a political nature. This capacity for objective scientific judgement has also been demonstrated by Dr. Weiss by the fact that in spite of his devotion to the school with which he has always indentified himself he never failed to express any objections he might have to the thoughts of this school. As to Weiss' scientific work it is too great and too important to be thoroughly discussed in this tribute. As an introduction to this part of the paper I shall quote the Editor of the Folia without having asked his permission. I believe that it will greatly please the man to whom the paper is dedicated to read what was written by Professor Luchsínger, the eminent logopedist and phoniatrician, in answer to my offer to write the tribute. «He has seen since the Viennese Days the great rise of Logopedics and Phoniatrics of which we can be proud and the important contributions which he himself has made to this science.» I can mention only a few of Weiss' sixty-four publications and these are not necessarily the most important to every reader for all of his scientific work is significant. First I want to mention his papers on Stroboscopy and the paper on Resonance of the Voice. Then there is his important work on the Problem of the Pubertal Change of the Voice with the findings concerning the differences between the child's voice and the postmutational high voice. Again pertaining to voice is the paper on Voice Registers. He has written Basic Ideas on the Question of Phonasthenia and has made a most significant contribution to the Discussion of the Neurochronaxic Theory (Husson). There are five contributions on Cluttering, a subject with which Weiss's name is especially identified. Not only has he given the classical description of symptoms and of the therapy but his invention of the term Central Language Imbalance sheds light upon the real essence of this disturbance. In 
another area is his paper on Experimental Phonetics and the Wholistic Theory. He has written on the Problem of the Faults in Orthography and on Some Borderline Problems of Psychiatry and Speech Pathology. This last article is an example of Weiss' mastery of a great part of medicine. In all of his work one is

To Deso A. Weiss' 60th Birthday

163

impressed not only with this man's knowledge of the literature but with his respect for what has been done by other scientists.

Weiss is well known for his "practical" work as a practitioner in logopedics and phoniatrics in the U.S.A. as he was in Europe and in Cuba. He is at present a leading psychiatrist in a State Hospital where he and his staff treat 650 insane patients. The fact that he does this job tirelessy, still maintaining his enthusiasm for all of his scientific interests proves that he is an elastic, vigorous man whose somatic as well as mental-psychologic personality contradicts the calendar which makes him 60 years old. Of the many "extra curricular" contributions which Weiss has made to our branch of science perhaps the greatest is his work for the International Societv for Logopedics and Phoniatrics. As Vice-President of a smaller group, The New York Society for Speech and Voice Therapy, his help has also proved to be invaluable. Another contribution comes through his position as Coeditor of the Folia Phoniatrica. Those of us who know all facts mentioned will not forget his capacities as a multi-linguist which enhance the rest of his great capabilities. Recently The American Speech and Hearing Association has made Weiss a Fellow. Other societies which have made him an honorary member are the Italian Society of Experimental Phonetics, Biological Phonetics, Phoniatry and Otology, the Argentine and the Cuban Societies for Logopedics and Phoniatrics.

To congratulate such a personality means not only to express best wishes for health and happiness for his sake, but the "ad multos annos" involves an egotistical desire of many people who appreciate their privilege of knowing him, among those his friend,

Emíl Froeschels

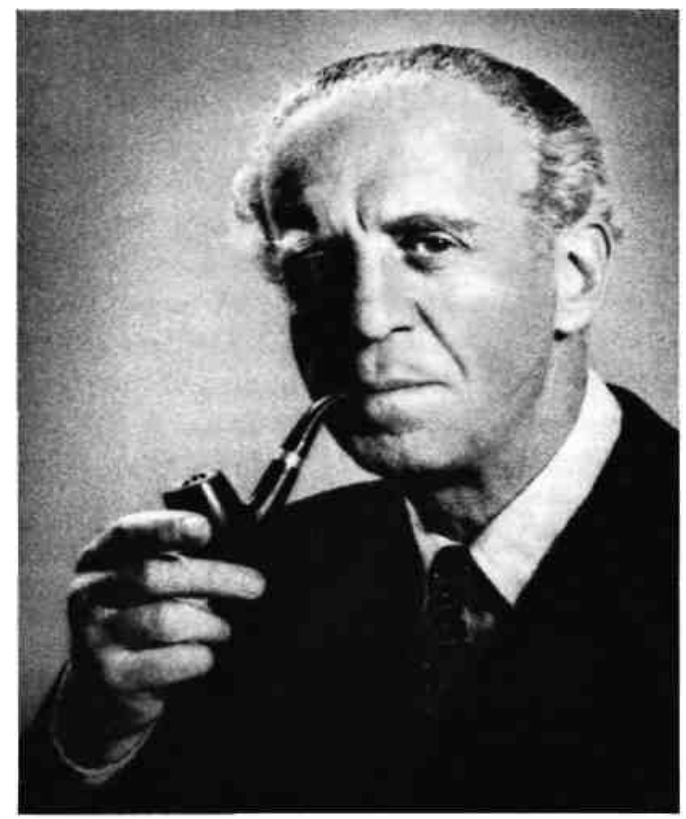

